\title{
BESARI ( BETON SISA INDUSTRI ) FOR SUSTAINABLE DEVELOPMENT
}

\author{
Arruna Rodhi Prasetya ${ }^{1}$, Fadhilah Arifatunnisa ${ }^{2}$, Riztira Yeca Tiya Milleda ${ }^{3}$
}

\footnotetext{
${ }^{1}$ Universitas Muhammadiyah Surakarta, arrun.prasetya@gmail.com

${ }^{2}$ Uiversitas Muhammadiyah Surakarta, farifannisa@gmail.com

${ }^{3}$ Universitas Muhammadiyah Surakarta, riztiramilleda@gmail.com
}

\begin{abstract}
Abstrak:High density concrete atau beton berat merupakan beton yang dihasilkan dari agregat yang mempunyai berat isi lebih besar dari berat beton normal. Beton yang mempunyai berat yang tinggi ini biasanya digunakan untuk kepentingan tertentu seperti menahan radiasi, menahan benturan dan lainnya. Untuk membuat beton tersebut diperlukan inovasi material yang berasal dari limbah, selain menghasilkan berat isi yang tinggi juga terciptanya beton ramah lingkungan. Tujuan penelitian ini, pembuatan beton ramah lingkungan kami beri nama BESARI (Beton Sisa Industri) dengan pembuatan beton SCC (Self Compacting Concrete) yang memanfaatkan limbah industri yaitu limbah steel slag dan granit sebagai pengganti agregat kasar, serbuk besi sebagai pengganti agregat halus, serta serbuk marmer sebagai filler dalam substitusi semen. Limbah yang kami gunakan didapatkan dari daerah sekitar Klaten dan Surakarta. Dengan menggunakan metode perencanaan American Concrete Instituted (ACI) dan standar EFNARC, pembuatan beton berjumlah 3 silinder ukuran $15 \mathrm{~cm}$ x $30 \mathrm{~cm}$ dan 1 kubus ukuran $15 \mathrm{~cm} \times 15 \mathrm{~cm}$ dengan rancangan penambahan serbuk besi $(10 \%)$ dari total agregat halus, steel slag (50\%) dan granit (50\%) dari total agregat kasar, serbuk marmer $(10 \%)$ dari total semen, serta penambahan Sika Viscocrete 1003 sebesar 1,5\% digunakan di Laboratorium Teknik Sipil Universitas Muhammadiyah Surakarta, dengan f'cr 45 MPa. Penelitian ini diharapkan dapat menjadi inovasi beton sustainable, ramah lingkungan, efisien, serta ekonomis dari pada beton konvensional.
\end{abstract}

Kata-kata kunci: High Density Concrete, Beton SCC, Limbah Industri, Ramah Lingkungan

Abstract: High density concrete or heavy concrete is concrete produced from aggregates that have a density greater than the weight of normal concrete. Concrete that has a high weight is usually used for certain purposes such as resisting radiation, resisting impact and others. To make the concrete, it is necessary to innovate materials derived from waste, in addition to producing a high density, the creation of environmentally friendly concrete. The purpose of this research is to produce environmentally friendly concrete named BESARI (Industrial Residual Concrete) with the manufacture of SCC (Self Compacting Concrete) concrete that utilizes industrial waste, namely steel slag and granite as a substitute for coarse aggregate, iron powder as a substitute for fine aggregate, and powder marble as filler in cement substitution. The waste we use is obtained from the area around Klaten and Surakarta. By using the American Concrete Instituted (ACI) planning method and the EFNARC standard, the production of concrete consists of 3 cylinders measuring $15 \mathrm{~cm} \times 30 \mathrm{~cm}$ and 1 cube measuring $15 \mathrm{~cm} \times 15 \mathrm{~cm}$ with the design of adding iron powder (10\%) of the total fine aggregate, steel slag (50\%) and granite (50\%) of the total coarse aggregate, marble powder (10\%) of the total cement, as well as the addition of Sika Viscocrete 1003 of $1.5 \%$ were used in the Civil Engineering Laboratory, University of Muhammadiyah Surakarta, with f'cr $45 \mathrm{MPa}$. This research is expected to be a sustainable, environmentally friendly, efficient, and economical concrete innovation compared to conventional concrete.

Keywords: High Density Concrete, SCC Concrete, Industrial Waste, Environmentally Friendly

\section{PENDAHULUAN}

High density concrete atau beton berat merupakan beton yang dihasilkan dari agregat yang mempunyai berat isi lebih besar dari berat beton normal atau lebih dari $2400 \mathrm{~kg}$ (Mulyono,2004). Untuk membuat beton berat dibutuhkan material inovasi yang memiliki berat jenis yang tinggi. 
48 JURNAL BANGUNAN, VOL. 26, NO.2, OKTOBER 2021: 47-62

Oleh karena itu, Najihah CUBE berinovasi memanfaatkan material yang berasal dari limbah. Najihah CUBE menggunakan bahan tambah steel slag dan granit sebagai substitusi agregat kasar, serbuk besi sebagai substitusi agregat halus, dan serbuk marmer sebagai substitusi semen

\section{a. Steel Slag}

Steel slag merupakan limbah yang dihasilkan dari hasil sisa produk peleburan baja atau besi dalam tanur. Dengan bentuk yang tidak beraturan, bertekstur kasar, berat jenis yang lebih besar dari pada batu alam, mempunyai ketahanan terhadap abrasi, karakteristik kekerasan yang bagus (PT. Ispat Indo, 2008). Berikut gambar dan kandungan unsur steel slag :

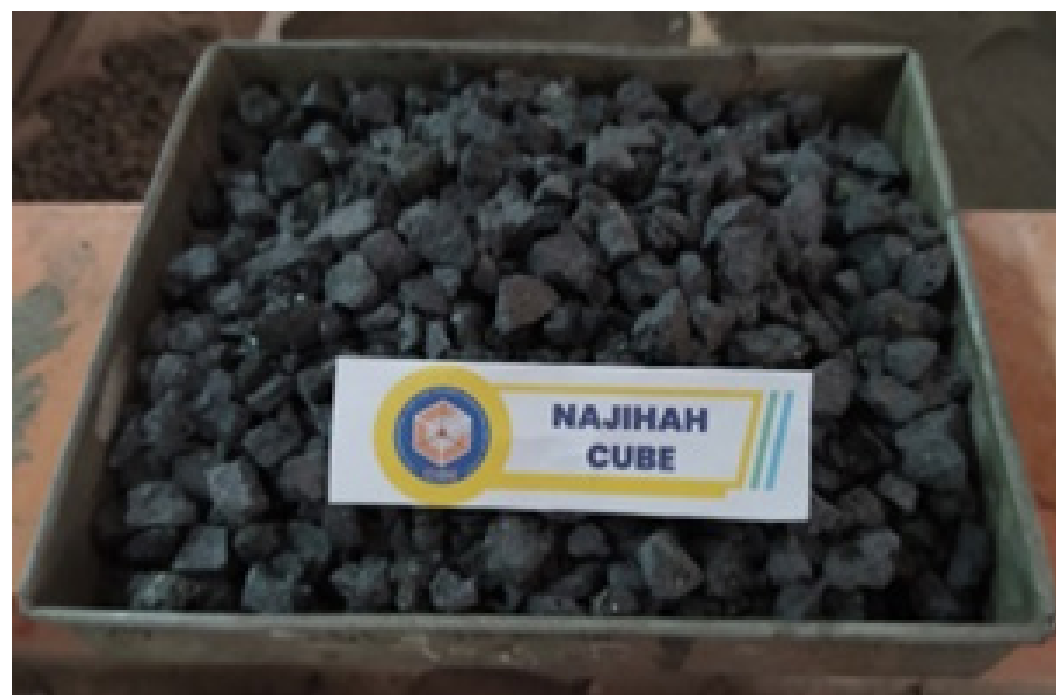

Gambar 1. Steel Slag

Tabel 1. Kandungan Unsur Steel Slag

\begin{tabular}{ll}
\hline \multicolumn{1}{c}{ Unsur Kimia } & \multicolumn{1}{c}{ Konten (\%) } \\
\hline $\mathrm{CaO}$ & $40-52$ \\
\hline $\mathrm{SiO} 2$ & $10-19$ \\
\hline $\mathrm{FeO}$ & $10-40$ \\
\cline { 2 - 2 } & $(70 \%-80 \% \mathrm{FeO}, 20 \%-30 \% \mathrm{Fe} 2 \mathrm{O} 3)$ \\
\hline $\mathrm{MnO}$ & $5-8$ \\
\hline $\mathrm{MgO}$ & $5-10$ \\
\hline $\mathrm{A} 12 \mathrm{O} 3$ & $1-3$ \\
\hline $\mathrm{P} 2 \mathrm{O} 5$ & $0,5-1$ \\
\hline $\mathrm{S}$ & $<0,1$ \\
\hline Metallic Fe & $0,5-10$
\end{tabular}

Sumber: (Haikal,dkk ,2014)

Menurut Jati Iswardoyo (2016) keuntungan penggunaan steel slag dalam campuran beton sebagai berikut : mempertinggi kekuatan tekan beton karena kecenderungan melam- 
batnya kenaikan kekuatan tekan, menaikkan rasio antara kelenturan dan kuat tekan beton, mengurangi serangan alkali-silika, mengurangi panas hidrasi dan menurunkan suhu, mempertinggi keawetan karena pengaruh perubahan volume. Limbah ini memiliki ketersediaan cukup banyak di daerah Ceper, Klaten. Dengan karakteristik dari steel slag tersebut, maka limbah steel slag cocok untuk dijadikan sebagai bahan substitusi agregat kasar.

\section{b. Pecahan Batu Granit}

Pecahan batu granitmerupakan limbah dariproses pengolahan batualam yang digunakan sebagai hiasanlantaiataudindingsuatubangunandanpembuatankijingdidaerahTirtonadi,Surakarta.Dalam bentukbatualamnyakarakteristikbatugranitmenyerupaiagregatkasardanmengandungunsur-unsur silica, A1, Fe, Ca, K dan V. dan senyawa mineralnya yaitu, $\mathrm{SiO}$, A12O3, Fe2O3, CaO, K2O, P2O5.

Berdasarkan SNI 24172008 Syarat keausan untuk agregat kasar yaitu < 40\%. Dari hasil uji, kami mendapatkan hasil bahwa pecahan granit tersebut memenuhi syarat keausan agregat kasar dan dapat digunakan sebagai subtitusi terhadap agregat kasar.



Gambar 2. Pecahan Batu Granit

Tabel 2. Pengujian Keausan Pecahan Granit

\begin{tabular}{cll}
\hline No & \multicolumn{1}{c}{ Keterangan } & Berat (gram) \\
\hline 1 & Berat Benda Uji (A) & 5000 \\
\hline 2 & a. Lolos 19 mm tertahan 12,5 mm $=2500 \mathrm{gr}$ & 2500 \\
\cline { 2 - 3 } & b. Lolos 12,5 mm tertahan 9 mm $=2500 \mathrm{gr}$ & 2500 \\
\cline { 2 - 3 } & Tertahan Saringan no. 12 $(\mathrm{B})$ & 3785 \\
\hline 3 & Presentasi keausan & $23,30 \%$ \\
\hline
\end{tabular}

Sumber : Laboratorium Teknik Sipil Universitas Muhammadiyah Surakarta 


\section{c. Serbuk Marmer}

Limbah marmer merupakan hasil dari proses pemotongan dan penggergajian batu marmer. Limbah tersebut berupa pecahan batu dan residu yang berwujud serbuk marmer. Penggunaan serbuk marmer pada beton memberikan keuntungan karena butirannya yang halus dapat mengisi ruang antar agregat dan menjadikan beton semakin kohesif dan meningkatkan kerapatan beton, serta mengurangi dampak limbah terhadap lingkungan juga menghasilkan beton dengan sifat mekanik yang lebih baik.(Handayani, 2014). Limbah ini memiliki ketersediaan cukup banyak di daerah Mojosongo, Surakarta. Dengan karakteristik dari serbuk marmer tersebut maka limbah serbuk marmer cocok untuk dijadikan sebagai bahan pengisi atau filler.



Gambar 3. Serbuk Marmer

Tabel 3. Komposisi Kimia Serbuk Marmer

\begin{tabular}{|c|c|}
\hline Unsur Kimia & Konten (\%) \\
\hline $\mathrm{SiO} 2$ & 17,63 \\
\hline $\mathrm{CaCO} 3$ & 2,73 \\
\hline $\mathrm{CaO}$ & 1,53 \\
\hline $\mathrm{MgO} 3$ & 0,20 \\
\hline $\mathrm{MgO}$ & 0,09 \\
\hline $\mathrm{Fe} 2 \mathrm{O} 3$ & 0,01 \\
\hline $\mathrm{AlO3}$ & 0,002 \\
\hline
\end{tabular}

Sumber : (Handayani, 2014)

\section{d. Serbuk besi}

Menurut Daryus, A.(dalam Bahri, S., \& Irawan, D. A. S, 2010), serbuk besi adalah hasil dari sisa potongan atau sisa pembubutan besi tuang yang merupakan hasil pemakaian di industri.Secara umum serbuk besi mengandung kimia seperti tertera dalam tabel 4 . 
Limbah serbuk besi memiliki kesamaan karakteristik dengan pasir dilihat dari ukuran maupun gradasinya. Pembuatan beton dengan menggunakan serbuk besi diharapkan mampu memanfaatkan limbah serbuk besi yang telah tidak terpakai lagi. Hasil penelitian menunjukkan bahwa terdapat pengaruh yang cukup signifikan dengan adanya penambahan serbuk besi. Limbah ini memiliki ketersediaan cukup banyak di daerah Ceper, Klaten. Dengan karakteristik dari serbuk besi tersebut, maka limbah serbuk besi cocok untuk dijadikan sebagai bahan substitusi agregat halus.

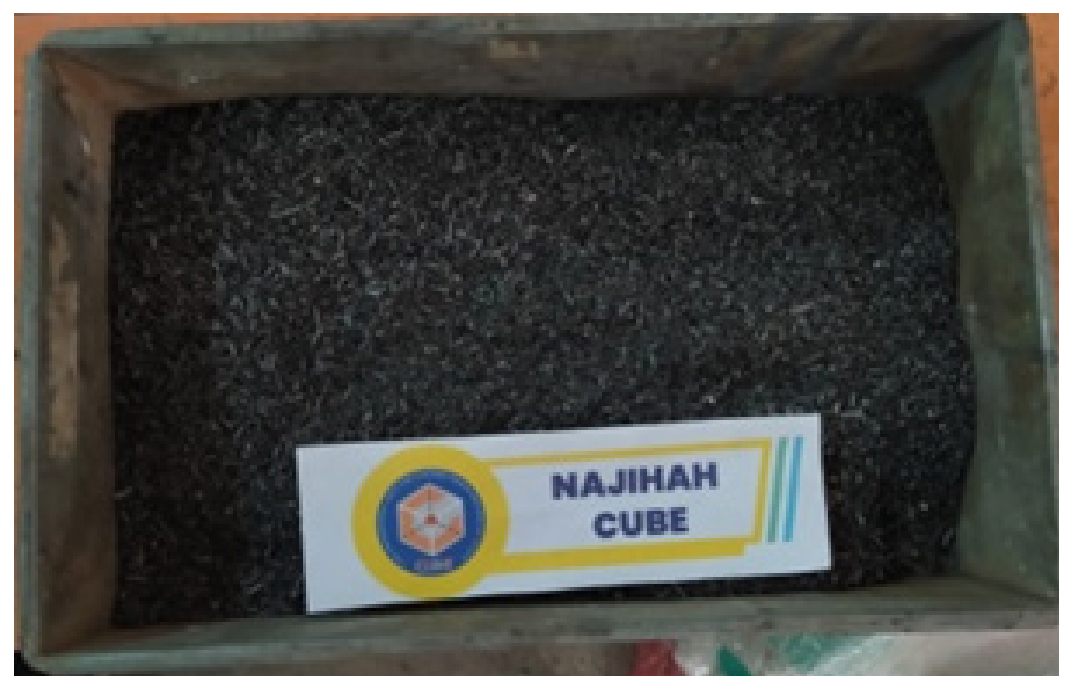

Gambar 4. Serbuk Besi

Tabel 4. Kandungan Kimia Serbuk Besi

\begin{tabular}{lll}
\hline \multicolumn{1}{c}{ Unsur Kimia } & Konten ( \%) \\
\hline Silikon $(\mathrm{Si})$ & $1-3$ & \\
\hline Carbon $(\mathrm{C})$ & $2-4$ \\
\hline Mangan $(\mathrm{Mn})$ & 0,8 \\
\hline Fospor $(\mathrm{P})$ & 0.1 \\
\hline Sulfur $(\mathrm{S})$ & 0.05 & \\
\hline Besi $(\mathrm{Fe})$ & Sisa &
\end{tabular}

Sumber : (Bahri, S., \& Irawan, D. A. S, 2010)

\section{e. Superplasticizer Type F}

High Range Water Reducing Admixture adalah bahan tambah yang berfungsi untuk mengurangi jumlah air pencampur 12\% atau lebih untuk menghasilkan beton dengan konsistensi yang telah ditetapkan (SNI 03- 2495-1991). Superplasticizer yang digunakan adalah produk dari PT. SIKA Indonesia yaitu Sika Viscocrete 1003. Sika Viscocrete 1003 dapat mengurangi penggunaan air, sehingga meningkatkan kuat tekan beton, mengurangi resiko bleeding dan segregasi pada beton 


\section{METODE}



Gambar 5. Flow Chart Metode Pelaksanaan

Metode pelaksanaan penelitian yang dilakukan meliputi hal-hal sebagai berikut :

\section{a. Persiapan bahan}

Semua bahan yang diperlukan dalam penelitian ini dipersiapkan dan disimpan di Laboratorium Teknik Sipil Fakultas Teknik Universitas Muhammadiyah Surakarta. Mulai dari semen, agregat halus, agregat kasar, air, serbuk marmer, steel slag, serbuk besi, pecahan batu granit dan 
bahan lain yang digunakan. Berikut beberapa bahan penelitian yang digunakan :

1) Pasir

2) Serbuk Marmer

3) Serbuk Besi

4) Steel Slag

5) Pecahan Batu Granit

6) Semen PPC (Portland Pozzolan Cement)

7) Air dari Laboratorium Teknik Sipil UMS.

8) Faktor air semen yang dipakai 0,25

9) Sika Viscocrete 1003

\section{b. Persiapan Alat Penelitian}

Berikut beberapa alat penelitian yang digunakan :

1) Alat uji tekan beton : menggunakan Universal Testing Mechine (UTM).

2) Timbangan digital

3) Gelas ukur

4) Ayakan

5) Wadah pencampuran beton

6) Cetakan beton silinder (Bekesting)

7) Sekop

\section{c. Pengujian bahan campuran beton}

Meliputi pengujian agregat kasar, halus dan semen.

\section{d. Pembuatan rencana campuran (mix design)}

Rencana campuran semen dan agregat-agregat sangat penting untuk mendapatkan kekuatan beton yang diinginkan. Dalam penelitian ini rencana campuran beton menggunakan metode ACI , f'cr $=45 \mathrm{MPa}$.

\section{e. Langkah-langkah pembuatan benda uji :}

1) Setelah bahan-bahan material dipersiapkan / ditimbang. Kemudian mencampurkan agregat kasar, agregat halus, dan semen. Setelah tercampur merata, lalu dilakukan penambahan air secara bertahap dan juga admixture sesuai takaran yang telah ditentukan sebelumnya sampai bahan adukan tercampur merata yang dilakukan dengan pengamatan visual. 2) Setelah material tercampur merata, lalu sebagian adukan diambil untuk dilakukan uji slump. Setelah pengujian slump memenuhi syarat maka dilanjutkan dengan penuangan adukan ke dalam cetakan silinder. 


\section{f. Pengujian Berat Isi Beton}

Pengujian berat isi beton dilakukan pada saat masih segar dan pada kondisi kering (umur 28 hari). Pengujian dilakukan dengan cara menimbang cetakan beton 150 × $300 \mathrm{~mm}$ dalam kondisi kosong. Selanjutnya, melakukan penimbangan cetakan yang sudah diisi dengan adukan beton. Maka didapatkan berat bersih dari beton.

\section{g. Pengujian Berat Jenis Beton}

Pengujian dilakukan pada usia beton 7 hari dengan menggunakan beton berbentuk kubus ukuran 150x150x150 mm. pengujian dilakukan dengan cara menimbang spesimen beton yang sudah dering udara selama 24 jam. Selanjutnya melakukan penimbangan spesimen beton dengan kondisi berada di dalam air.

\section{h. Pelaksanaan Pengujian Kuat Tekan}

Alat yang digunakan adalah Universal Testing Machine (UTM) dengan cara meletakkan silinder beton tegak lurus (vertikal). Khusus untuk pengujian kuat tekan, sebelum dilakukan pengujian permukaan tekan benda uji silinder harus rata agar tegangan terdistribusi secara merata pada penampang benda uji. Setelah itu nyalakan mesin UTM, pastikan beton yang akan diuji sudah menempel bagian permukaan atas dan bawah dengan alat uji. Kemudian buka sedikit demi sedikit tuas gas pada mesin sampai jarum bergerak, amati dan catat kuat tekan maksimum dari benda uji.

\section{i. Menghitung Hasil Kuat Tekan}

Dalam penelitian ini, beton yang telah di uji kuat tekannya kita mendapatkan besarnya kuat tekan beton dan kualitasnya. Sehingga kami dapat menganalisa beton yang bermutu baik dengan kuat tekan yang tinggi yang sesuai dengan kuat tekan rencana.

\section{Pengujian Material}

\section{Pasir dan Serbuk Besi}

a. Berat jenis (SSD) (SNI 03-1970-2008)

Untuk mengetahui kekeringan agregat halus sebenarnya dan untuk mengetahui keadaan agre gat halus dalam kondisi Saturated Surface Dry (SSD).

b. Berat jenis bulk (bulk specific gravity) (SNI 03-1970-2008)

Berat jenis bulk (bulk specific gravity) adalah perbandingan antara berat jenis agregat kering dengan air suling yang isinya sama dengan isi agregat dalam keadaan jenuh pada suhu ter tentu.

c. Modulus kehalusan butir (SNI 03-1968-1990)

Pemeriksaan Gradasi agregat dilakukan guna mendapatkan nilai modulus halus butir (MHB). 
Modulus halus butir adalah suatu nilai yang digunakan untuk menjadi ukuran kehalusan atau kekasaran butir agregat. Semakin besar nilai MHB, semakin menunjukan butir - butir agre gatnya besar.

d. Kandungan lumpur (SNI 03-4142-1996)

Metode pengujian jumlah bahan dalam agregat yang lolos saringan Nomor $200(0,075 \mathrm{~mm})$ dimaksudkan mengetahui kadar lumpur pada agregat halus dengan proses pencucian.

e. Penyerapan (Absorbsi) (SNI 03-1970-2008)

Penyerapan (absorbsi) adalah persentase berat air yang dapat diserap pori terhadap berat agregat kering.

f. Kandungan organik (SNI 03-2816-1992)

Metode ini dimaksudkan untuk menentukan adanya bahan organik dalam agregat halus alam yang akan digunakan sebagai bahan campuran mortar dan beton.

\section{Pecahan Batu Granit dan Steel Slag}

a. Berat jenis (SSD) (SNI 1969:2008)

Berat jenis kering permukaan jenuh (saturated surface dry) yaitu berat jenis agregat kasar dalam kondisi jenuh permukaan.

b. Berat jenis bulk (bulk specific gravity) (SNI 1969:2008)

Berat jenis bulk (bulk specific gravity) adalah berat jenis agregat yang memperhitungkan berat agregat kasar dalam keadaan kering dengan seluruh volume agregat.

c. Modulus kehalusan butir (SNI 03-1968-1990)

Pemeriksaan modulus halus agregat kasar adalah salah satu cara untuk mengetahui nilai ke halusan atau kekasaran suatu agregat. Kehalusan atau kekasaran agregat dapat mempenga ruhi kelecakan dari mortar beton, apabila agregat halus yang terdapat dalam mortar terlalu banyak akan menyebabkan lapisan tipis dari agregat halus dan semen akan naik ke atas.

d. Kandungan lumpur (SNI S-04-1989-F)

Agregat tidak boleh mengandung lumpur lebih dari 1\% terhadap berat kering awal, yaitu bah an-bahan yang dapat melalui ayakan $0,25 \mathrm{~mm}$. Apabila melebihi $1 \%$, maka agregat harus dicuci.

e. Penyerapan (Absorbsi) (SNI 1969:2008)

Penyerapan (Absorbsi) adalah penambahan berat dari suatu agregat akibat air yang meresap kedalam pori-pori, tetapi belum termasuk air yang tertahan pada permukaan luar partikel, dinyatakan sebagai presentase dari berat keringnya, agregat dikatakan "kering" ke tika dijaga pada suatu temperatur $(110 \pm 50)^{\circ} \mathrm{C}$ dalam rentang waktu yang cukup untuk meng hilangkan seluruh kandungan air yang ada (sampai beratnya tetap). 
f. Tingkatan abrasi (SNI 2417-2008)

Metode ini dimaksudkan sebagai pegangan dalam pemeriksaan untuk menentukan ketahanan agregat kasar terhadap keausan dengan menggunakan mesin abrasi Los Angeles

\section{Proporsi Campuran High Density Concrete Menggunakan Metode ACI}

\section{Menentukan fc'r}

Estimasi fc'r adalah $45 \mathrm{MPa}$

2. Informasi material

\section{Menetukan Slump}

Slump yang dipilih adalah $650 \mathrm{~mm}-800 \mathrm{~mm}$

4. Menentukan ukuran Agregat kasar

Ukuran maksimal agregat kasar adalah $20 \mathrm{~mm}$

5. Tentukan kandungan air dan udara.

Tabel 5. Estimasi Kandungan Air dan Udara untuk Slump dan ukuran maksimal split (ACI 211.1)

\begin{tabular}{cccccccc}
\hline \multirow{2}{*}{$\begin{array}{c}\text { Slump } \\
(\mathbf{m m})\end{array}$} & \multicolumn{7}{c}{ Air $\left(\mathbf{~ k g} / \mathbf{m}^{\mathbf{3}}\right)$} \\
\cline { 2 - 8 } & $\mathbf{1 0}$ & $\mathbf{1 2 , 5}$ & $\mathbf{2 0}$ & $\mathbf{2 5}$ & $\mathbf{4 0}$ & $\mathbf{5 0}$ & $\mathbf{7 0}$ \\
\cline { 2 - 8 } & 205 & 200 & 185 & 180 & 160 & 155 & 145 \\
\hline $\mathbf{3 0 - 5 0}$ & 225 & 225 & 200 & 195 & 173 & 170 & 160 \\
\hline $\mathbf{8 0 - 1 0 0}$ & 240 & 240 & 210 & 205 & 185 & 180 & 170 \\
\hline $\mathbf{1 5 0 - 1 8 0}$ & 3 & 2,5 & 2 & 1,5 & 1 & 0,5 & 0,3 \\
\hline Udara & & & &
\end{tabular}

Berdasarkan nilai slump dan ukuran split dengan kadar udara $1 \%$ diperoleh kadar air. Namun tabel tersebut digunakan untuk beton konvensional, setelah melakukan trial error diperoleh kadar air sebesar $185,5 \quad 1 / \mathrm{m}^{3}$. 6. Menentukan w/c

Tabel 6. Korelasi antara Kuat Tekan Beton dan w/c (ACI 211.1)

\begin{tabular}{cc}
\hline Kuat Tekan Pada Hari Ke 28 & Rasio Air Semen \\
\hline (Mpa) & 0,35 \\
\hline 42 & 0,44 \\
\hline 35 & 0,53 \\
\hline 28 & 0,62 \\
\hline 22,4 & 0,71 \\
\hline 17,5 & 0,80 \\
\hline 14 & 0,79 \\
\hline 15 &
\end{tabular}

Berdasarkan nilai fc'r yaitu $45 \mathrm{MPa}$, maka rasio air semen yang digunakan yang terkecil berdasarkan Tabel 6 . yaitu 0,35 . 
7. Menentukam Cement Content

Dari langkah 5 dan 6, cement content $=\mathrm{W} /(\mathrm{w} / \mathrm{c})=185,5 / 0.35=530 \mathrm{~kg} / \mathrm{m} 3$.

8. Menentukan Binder Content

Dari beberapa percobaan yang telah dilakukan, diperoleh proporsi bahan pengikat sebagai berikut:

Tabel 7. Bahan Pengikat Tambahan

\begin{tabular}{lll}
\hline Semen & 530 & $\mathrm{~kg} / \mathrm{m}^{3}$ \\
\hline Serbuk Marmer (10\%) & 53 & $\mathrm{~kg} / \mathrm{m}^{3}$ \\
\hline Semen Titius & 583 & $\mathrm{~kg} / \mathrm{m}^{3}$ \\
\hline
\end{tabular}

9. Menghitung kadar air setelah penambahan pengikat suplementer untuk mengetahui kandungan air, pengikat total dikalikan dengan $\mathrm{w} / \mathrm{c}=583 \times 0,35=204,1 \mathrm{l} / \mathrm{m} 3$.

10. Menghitung pemakaian admixture yakni Sika Viscocrete-1003.

Dari percobaan yang kami lakukan, mencapai dosis optimum 1,5\%. Jadi 1,5\% x 583 = 8,75 1/ $\mathrm{m} 3$. Sika Viscocrete 1003 dapat mengurangi air hingga 30\%, namun pada saat trial hanya dapat mengurangi 28,5\%, Maka jumlah air 204,1- $\left(28,5 \%\right.$ x 204,1) $=145,91 / \mathrm{m}^{3}$. Dengan menurunnya penggunaan air, maka f.a.s juga menurun, yaitu menjadi 0.25

\begin{tabular}{|c|c|c|c|}
\hline \multicolumn{4}{|c|}{ Tabel 8. Perhitungan Mix Design BESARI } \\
\hline Bahan & Berat Jenis & \multicolumn{2}{|c|}{ Satuan } \\
\hline Semen PPC Gresik & 3150 & \multicolumn{2}{|c|}{$\mathrm{kg} / \mathrm{m}^{3}$} \\
\hline Pasir & 2600 & \multicolumn{2}{|c|}{$\mathrm{kg} / \mathrm{m}^{3}$} \\
\hline Granit & 3027 & \multicolumn{2}{|c|}{$\mathrm{kg} / \mathrm{m}^{3}$} \\
\hline Steel slag & 3300 & \multicolumn{2}{|c|}{$\mathrm{kg} / \mathrm{m}^{3}$} \\
\hline Serbuk Besi & 2900 & \multicolumn{2}{|c|}{$\mathrm{kg} / \mathrm{m}^{3}$} \\
\hline Serbuk Marmer & 2790 & \multicolumn{2}{|c|}{$\mathrm{kg} / \mathrm{m}^{3}$} \\
\hline Water binder $(\mathrm{w} / \mathrm{b})$ & \multicolumn{3}{|c|}{0,25} \\
\hline \multirow[t]{2}{*}{ Material } & Berat & \multicolumn{2}{|c|}{ Volume } \\
\hline & $(\mathrm{kg})$ & Vol & Komulatif \\
\hline Kadar Udara & $1 \%$ & 0,010 & 0,010 \\
\hline Kadar Air & 145,9 & 0,056 & 0,066 \\
\hline Semen & 530 & & \\
\hline Serbuk Marmer & 53 & & \\
\hline Binder content & 583 & 0,224 & 0,290 \\
\hline Agregat Halus (60\%) & & 0,388 & 0,678 \\
\hline Pasir & 922,22 & 0,344 & \\
\hline Serbuk Besi & 114,29 & 0,044 & \\
\hline Agregat Kasar (40\%) & & 0,319 & 0,997 \\
\hline Granit & 397,66 & 0,153 & \\
\hline Steel slag & 433,52 & 0,166 & \\
\hline Sika Viscocrete 1003 & 8,75 & 0,003 & 1,000 \\
\hline Density & & 2605,331 & \\
\hline
\end{tabular}




\section{HASIL PENGUJIAN}

a. Pengujian Slump

Tabel 9. Hasil Pengujian Slump

\begin{tabular}{cc}
\hline Diameter & Slump Flow (mm) \\
\hline $\mathrm{d} 1$ & 680 \\
\hline $\mathrm{d} 2$ & 700 \\
\hline Slump Flow & 690 \\
\hline
\end{tabular}

b. Pengujian Berat Isi Beton Segar (fresh concrete)

Pengujian berat isi beton segar dilakukan pada beton berbentuk silinder 150 x $300 \mathrm{~mm}$ pada saat kondisi masih segar.

Tabel 10. Hasil Pengujian Berat Isi Beton pada kondisi Fresh Concrete

\begin{tabular}{ccccc}
\hline \multirow{2}{*}{ Silinder } & $\mathbf{M c}$ & $\mathbf{M m}$ & $\mathbf{V m}$ & $\mathbf{D}$ \\
\cline { 2 - 5 } & $\mathbf{( k g )}$ & $\mathbf{( k g )}$ & $\left.\mathbf{( m}^{\mathbf{3}}\right)$ & $\mathbf{( \mathbf { ~ k g } / \mathbf { m } ^ { 3 } \mathbf { ) }}$ \\
\hline 1 & 24 & 10.6 & 0.0052 & 2599.15 \\
\hline 2 & 26.13 & 12.61 & 0.0052 & 2622.42 \\
\hline 3 & 25.42 & 12.1 & 0.0052 & 2582.67 \\
\hline \multicolumn{5}{c}{ Berat Isi Segar } \\
\hline \multicolumn{5}{c}{}
\end{tabular}

c. Pengujian Berat Jenis Beton Kering (dried concrete)

Pengujian berat jenis beton kering dilakukan pada beton berbentuk kubus 150 x 150 x $150 \mathrm{~mm}$ pada usia 7 hari.

Tabel 11. Hasil Pengujian Berat Jenis

\begin{tabular}{cc}
\hline Pengujian & Hasil Pengujian \\
\hline & $\mathbf{( k g )}$ \\
\hline Berat di udara & 8.7 \\
\hline Berat di dalam air & 5.34 \\
\hline Berat jenis & 2.59 \\
\hline
\end{tabular}

d. Pengujian Berat Isi Beton Kering (dried concrete)

Pengujian berat isi beton kering dilakukan pada beton berbentuk silinder 150 x $300 \mathrm{~mm}$ pada usia 28 hari.

Tabel 12. Hasil Pengujian Berat Isi Beton Pada Kondisi Dried Concrete

\begin{tabular}{cccc}
\hline \multirow{2}{*}{ Silinder } & $\mathbf{M}$ & $\mathbf{V m}$ & $\mathbf{D}$ \\
\cline { 2 - 4 } & $\mathbf{( k g )}$ & $\left.\mathbf{( m}^{\mathbf{3}}\right)$ & $\left.\mathbf{( ~ k g / \mathbf { m } ^ { 3 }}\right)$ \\
\hline 1 & 13.34 & 0.0052 & 2586.55 \\
\hline 2 & 13.43 & 0.0052 & 2604 \\
\hline 3 & 13.18 & 0.0052 & 2555.53 \\
\hline \multicolumn{3}{c}{ Berat Isi Kering } & 2582.03 \\
\hline
\end{tabular}


e. Pengujian Kuat Tekan Beton

Pengujian kuat tekan dilakukan pada beton berbentuk silinder 150 x 300 mm pada usia 28 hari.

\begin{tabular}{|c|c|c|}
\hline \multirow{2}{*}{ Silinder } & \multicolumn{2}{|c|}{ Umur 28 hari } \\
\hline & $\mathbf{k N}$ & MPa \\
\hline 1 & 490 & 27.74 \\
\hline 2 & 940 & 53.22 \\
\hline 3 & 800 & 45.29 \\
\hline & Kuat tekan & 42.09 \\
\hline
\end{tabular}

\section{PEMBAHASAN}

\section{a. Analisa Inovasi Beton dari Segi Mutu, Inovasi, dan Biaya}

1) High Density Concrete

Beton "BESARI" memiliki keunggulan yaitu High Density, pada pengujian berat isi beton segar (fresh concrete) mendapatkan berat isi sebesar $2601.41 \mathrm{~kg}$. Pada pengujian berat isi beton kering (dried concrete) mendapatkan berat isi sebesar $2582.03 \mathrm{~kg}$. Berdasarkan hasil pengujian tersebut Beton "BESARI" dapat dikategorikan beton high density concrete, karena memiliki berat isi lebih besar dari beton normal.

2) Kuat Tekan

Pengujian kuat tekan beton "BESARI" dilakukan pada umur 28 hari, mendapatkan nilai kuat tekan sebesar 42,09 Mpa, hasil kuat tekan tersebut sesuai dengan kuat tekan yang direncanakan.

3) Waktu

Beton "BESARI" juga memiliki keunggulan lain pada segi mutu, yaitu waktu. Karena beton "BESARI" memiliki tingkat workabilitas yang tinggi dapat memadat dengan sendirin ya, sehingga dapat mengurangi waktu untuk pemadatan. Dengan demikian, dapat memper cepat proses pelaksanaan pembangunan.

4) Tingkat workability yang tinggi

Tingkat workabilitas yang tinggi sehingga dapat memdat dengan sendirinya, juga meru pakan keunggulan dari beton "BESARI". Maka dengan demikian, pada pelaksanaannya tidak diperlukan alat vibrator untuk proses pemadatan. Sehingga dapat mengurangi energi serta kebisingan yang ditimbulkan dari vibrator tersebut.

\section{5) Analisa Inovasi}

Beton "BESARI" sendiri bermanfaat untuk lingkungan, dan sosial yang dapat dilihat dari perbandingan proporsi yang digunakan jika dibandingkan dengan beton konvensional. Pemanfaatan serbuk marmer dan limbah pecahan granit dapat mengurangi limbah terhadap lingkungan serta dapat meningkatkan mutu dari beton.

Pemanfaatan steel slag dan limbah serbuk besi yang berasal dari limbah industri merupakan 
sebuah inovasi positif yang dapat mengurangi pencemaran lingkungan. Stel slag dan limbah serbuk besi termasuk limbah B3 yang berbahaya, sehingga kami memanfaatkan agar lebih berguna. Kedua bahan ini juga memiliki pengaruh yang cukup besar karena dapat mening katkan kuat tekan.

6) Segi Ekonomi

Beton "BESARI" juga memiliki keunggulan lain pada segi ekonomi, yaitu biaya. Karena beton "BESARI" memiliki biaya produksi yang lebih rendah daripada biaya produksi dari beton SCC konvensional. Dapat kita lihat dari tabel dibawah ini.

\begin{tabular}{|c|c|c|c|c|c|c|c|}
\hline \multirow[b]{2}{*}{ No } & \multirow[b]{2}{*}{ Bahan } & \multicolumn{3}{|c|}{ BESARI } & \multicolumn{3}{|c|}{ Beton Konvensional } \\
\hline & & $\begin{array}{c}\text { Harga } \\
\text { Satuan } \\
\text { (Rp) }\end{array}$ & $\begin{array}{c}\text { Kebutuhan } 1 \\
\mathrm{~kg} / \mathrm{m}^{3}\end{array}$ & $\begin{array}{l}\text { Harga } \\
\text { Produksi } \\
\text { (Rp) }\end{array}$ & $\begin{array}{c}\text { Harga } \\
\text { Satuan } \\
\text { (Rp) }\end{array}$ & $\begin{array}{c}\text { Kebutuhan } \\
1 \mathrm{~kg} / \mathrm{m}^{3}\end{array}$ & $\begin{array}{c}\text { Harga } \\
\text { Produksi } \\
\text { (Rp) }\end{array}$ \\
\hline 1 & Cement & $1.112,50$ & 530 & $589.625,00$ & $1.112,50$ & 583 & $648.587,50$ \\
\hline 2 & $\begin{array}{l}\text { Serbuk } \\
\text { Marmer }\end{array}$ & 50 & 53 & $2.650,00$ & - & - & - \\
\hline 3 & Pasir & 175 & 922,22 & $161.387,95$ & 175 & 886,49 & $155.135,14$ \\
\hline 4 & $\begin{array}{l}\text { Serbuk } \\
\text { Besi }\end{array}$ & 268 & 114,29 & $30.630,21$ & - & - & - \\
\hline 5 & \begin{tabular}{|l} 
Steel \\
Slag
\end{tabular} & 250 & 433,52 & $108.380,19$ & - & - & - \\
\hline 6 & Granit & 50 & 397,66 & $19.882,84$ & & - & - \\
\hline 7 & \begin{tabular}{|l|} 
Sika \\
Visco- \\
crete \\
1003 \\
\end{tabular} & 30 & 8,75 & $262.350,00$ & $30.000,00$ & 8,75 & $262.350,00$ \\
\hline 8 & Air & 50 & 145,9 & $7.295,00$ & 50 & 185 & $9.250,00$ \\
\hline \multirow[t]{2}{*}{9} & Split & - & - & - & 250 & 844,42 & $211.106,22$ \\
\hline & & Total & \multicolumn{2}{|c|}{$1.182 .201,19$} & Total & \multicolumn{2}{|c|}{$1.286 .428,86$} \\
\hline
\end{tabular}

Dengan demikian, dapat dikatakan bahwa "BESARI" lebih menghemat biaya produksi sebesar Rp. 104.227,68 atau sebesar 8,10\% daripada biaya produksi dari beton SCC konvensional.

\section{SIMPULAN}

Dari penelitian yang dilakukan tim Najihah CUBE dapat diambil kesimpulan sebagai berikut :

a. BESARI peduli dengan lingkungan karena memanfaatkan limbah yang ada di sekitar ling kungan, dengan memanfaatkan limbah industri yaitu steel slag dan granit sebagai pengganti agregat kasar, serbuk besi sebagai substitusi agregat halus, serta serbuk marmer sebagai substitusi semen.

b. BESARI merupakan beton self compacting yang memiliki density tinggi dan juga tingkat workability yang tinggi.

c. BESARI merupakan beton yang ekonomis dibandingkan dengan beton SCC konvensional, dapat menghemat biaya sebesar $8,10 \%$ dari biaya beton SCC konvensional. 


\section{DAFTAR RUJUKAN}

Handayani, A. F., Soehardjono, A., \& Zacoeb, A. (2015). Pemanfaatan Limbah Serbuk Marmer pada Beton sebagai Bahan Pengganti Sebagian Semen dengan Variasi Penggunaan Silica Fume. Teknologi dan Kejuruan: Jurnal teknologi, Kejuruan dan Pengajarannya, 37(2). http://journal.um.ac.id/index.php/teknologi-kejuruan/article/view/4434

Haikal, F., Ashadi, H. W., \& Nazech, E. M. (2014). Studi Pemanfaatan Limbah Steel Slag Seb agai Subtitusi Agregat Dalam Pembuatan Beton Geopolimer Berbahan Dasar Fly ash. Uni versitas Indonesia. Depok.

http://www.lib.ui.ac.id/abstrakpdf?id=20388324\&lokasi=lokal

Aditya, C., Halim, A., \& Silviana, S. (2016). Pemanfaatan Limbah Marmer dan Serbuk Silika pada Industri Bata Beton Pejal dan Berlubang. Prosiding SENIATI, 16-A.

https://ejournal.itn.ac.id/index.php/seniati/article/view/235

Iswardoyo, J. (2016). The Study Of Utilization Of Steel Slag To Sabodam. Jurnal Teknik Hi draulik, 7(2), 131-146.

https://jurnalth.pusair-pu.go.id/index.php/JTH/article/view/564

Purwanto, H., \& Wardani, U. C. (2020). Pengaruh Penambahan Serbuk Besi Terhadap Kuat Tekan Beton Mutu K225. Jurnal Deformasi, 5(2), 103-112.

https://jurnal.univpgri-palembang.ac.id/index.php/deformasi/article/view/5039

SNI 03-4142-1996, Metode Pengujian Jumlah Bahan Dalam Agregat Yang Lolos Saringan No.200 (0,075 mm), Badan Standarisasi Nasional

SNI 03-1970-2008, Metode Pengujian Berat Jenis Dan Penyerapan Air Agregat Halus,Badan Standarisasi Nasional

SNI 03-2816-1992, Metode Pengujian Kotoran Organik Dalam Pasir Untuk Campuran Mortar Atau Beton, Badan Standarisasi Nasional

SNI 1969:2008, Cara Uji Berat Jenis Dan Penyerapan Air Agregat Kasar, Badan Standarisasi Nasional

SNI 03-1968-1990, Metode Pengujian Tentang Analisis Saringan Agregat Halus Dan Kasar, Badan Standarisasi Nasional

SNI S-04-1989-F, Spesifikasi Bahan Bangunan Bagian A, Badan Standarisasi Nasional

SNI 2417-2008, Cara Uji Keausan Agregat Dengan Mesin Abrasi Los Angeles, Badan Stan darisasi Nasional

SNI 1972-2008, Cara Uji Slump beton, Badan Standarisasi Nasional 
62 JURNAL BANGUNAN, VOL. 26, NO.2, OKTOBER 2021: 47-62 